\title{
Application of Different Geotextile in Soil to Improve the Soil Health in Humid and Hot Sub Humid Region of West Bengal, India
}

\author{
Arunabha Pal ${ }^{1 *}$, Rahul Adhikary ${ }^{1}$, Monisankar Bera ${ }^{1}$, \\ Susnata Kumar De ${ }^{2}$ and Milan Sardar ${ }^{2}$ \\ ${ }^{1}$ Department of Agricultural Chemistry and Soil Science, \\ Centurion University of Technology and Management, Odisha, India, 761211 \\ ${ }^{2}$ Department Soil and Water Conservation, \\ Bidhan Chandra KrishiViswavidyala, Mohanpur, West Bengal, 741252, India
}

*Corresponding author

\section{Keywords}

Geotextile, Soil

Structure, Soil

Physical Properties,

Soil Chemical

Properties

Article Info

Accepted:

20 May 2020

Available Online:

10 June 2020

\begin{abstract}
A B S T R A C T
Geotextiles a natural product at eco-friendly and biodegradable in nature, act as useful ameliorative to climate the soil related constrains of crop production. Biodeterioration of cellulose fiber results from the reduction at die polymerization leading to loss textile strength. It also helps to protect the most vital natural resources of soil and water from various degradation processes by erosion of soil and runoff water. It plays a vital role in increasing moisture holding capacity in soil, improving water uptake and drainage capacity. Application of suitable ameliorative thus necessitates for improving various soil conditions towards increasing the crop productivity. The experiment was conducted with five treatments combinations viz. T1 -non woven jute geotextile, T2 - non woven dry grasses geotextile, T3 - non woven coco coir geotextile ,T4 - non woven banana leaf fibre geotextile and T5 - farmers practices (i.e. control). All geotextile materials @ 10 ton /ha were spread on the soil after final land preparation and before seedling or planting of vegetables. Application of different Geotextile treatments improves the physical and chemical environments in soil thus favouring better soil conditions and nutrient availabilities towards better growth and yield of vegetables.
\end{abstract}

\section{Introduction}

Jute agro geo-textiles as surface cover materials have various potentials for maintaining soil quality and protecting the soil against any form of degradation. Naturally occurring jute agro geo-textiles are eco-friendly and biodegradable products which act as surface cover materials and useful ameliorative to eliminate soil related constraints to crop production (Yong et al., 2000; Pain et al., 2013).

It also helps to protect the most vital natural resources against various degradation processes and promotes vegetative cover through accelerated seed germination and seedling emergence (Bhattacharya et al., 
2010). Natural geotextiles degrades to form organic mulch and held in weak establishment of vegetation. Jute geotextile degrades in 1 to 2 years, dry grasses, coco coir geotextile and Banana leaf fiber, geotextile degrades 1 to 2 to 3 years (Adhikary et al., 2019).

Geotextile application in soil location specific so in addition to the characteristics of geotextiles, identification and application of geotextiles depends on soil types, soil compaction, moisture content, liquid limits, plasticity index, bulk density, soil $\mathrm{pH}$, iron/ calcium content, clay / silt and sand composition, land sloping and hydrolic action (Adhikary et al., 2019).Geotextiles used for re-vegetation and soil stabilization and wherever the upper layer of the soil has to be preserved from wind and water erosion and conserved soil moisture during the establishment of a vegetation cover.

\section{Materials and Methods}

In order to investigate the application of different geotextile treatment on soil to improve the soil health in humid and hot sub humid region, experiment was carried out during 2015 - 2016 at Gokna village near Baduria North 24 Parganas West Bengal. The land is situated at $22^{\circ} 71^{\prime} \mathrm{N}$ latitude, $88^{\circ} 75^{\prime} \mathrm{E}$ longitudes with and altitude at $5 \mathrm{~m}$ above the mean sea level. The climate is subtropical moist sub humid with mean annual temperature of $36.4^{0} \mathrm{C}$ to $14.4^{0} \mathrm{C}$ and mean annual rainfall of $1503 \mathrm{~mm}$ (KrishiVigyan Kendra, Ashoknagar). The initial soil test conducted before doing the experiment showed in (Table No -1) and treatment details also described on (Table No-2).

\section{Results and Discussion}

Effect different geotextile after one year changes of soil physical and chemical properties presented in this section.

\section{Physical properties of soil}

The result of changes of various physical properties in soil due to application of various non- woven geotextile are presented in (Table 3) .The data reveals that variations of bulk density, porosity and water holding capacity in soil were detected due to variation of treatment combinations. The result shows minimum bulk density under jute geotextile treatment than the other treatment.

Bulk density showed to change with the following order. Jute geotextile $(1.20 \mathrm{~g} / \mathrm{cc})<$ Dry grasses geotextile $(1.23 \mathrm{gm} / \mathrm{cc})<$ Coco coir geotextile $(1.25 \mathrm{~g} / \mathrm{cc})<$ Banana leaf fibre geotextile $(1.27 \mathrm{~g} / \mathrm{cc})<\mathrm{control}(1.28 \mathrm{~g} / \mathrm{cc})$. The reduction of B.D. over control due to each treatment were $0.08(6.25 \%), 0.05(3.65 \%)$, $0.03(2.08 \%), 0.01(1.04 \%)$ respectively for jute fibre, Dry grasses, coco-coir and banana leaf fibre.

The results of porosity showed reverse trend of bulk density as it increases due to application of each treatments over control. Highest values are observed in the soil treated with jute geotextiles in every year (Table 3 ). Porosity showed to change with the following order Jute geotextile $(56.46 \%)>$ Dry grasses $(55.56 \%)>$ Coco coir geotextile $(51.76 \%)>$ Banana leaf fibre geotextile $(51.16 \%)>$ control $(49.9 \%)$. Increase porosity over control in each treatment was 6.57 (13.16\%), 5.67 (11.36\%), 1.87 (3.74\%), $1.27(2.54 \%)$ respectively. The above results supported by Nag et al., (2008).

The water holding capacity in soil also shows to vary significantly with the variation of various geotextiles application. At each of the geotextiles treatment the values of water holding capacity found to increase over control. Highest values are observed in the soil treated with jute geotextiles plots (Table $3)$. 
Increase of water holding capacity over control due to each treatment were jute geotextile $(58.4 \%)>$ Dry grasses $(57.8 \%)>$ Coco coir geotextile $(56.6 \%)>$ Banana leaf fibre geotextile $(55.2 \%)>$ control $(54.3 \%)$ increase of the value over control were $18.38 \%, \quad 14.56 \%, \quad 7.7 \%$ and $3.75 \%$ respectively for jute, Dry grasses, coco coir and banana leaf fibre geotextile.

Similar results also evidence by Booth et al., (2005) lowering bulk density and increasing the porosity and water holding capacity by the application of palm leaf geotextile for maintain of soil quality and soil conservation.

Soil aggregation is an important parameter of soil structure linked with various major functions in relation to soil management system. Stabilization of soil aggregates is often used as a measurement of soil structure, which mediates many important biological, chemical and physical processes in soil. Changes of some of such indicates like mean weight diameter, geometric mean diameter, water stability aggregates, percent aggregates stability and structural coefficient under the influence of geotextiles are presented in (Table 4).

The results found that all the soil structure and the stability of aggregation showed much variation due to variation of different treatments. Increases of MWD and GMD due to application of geotextiles are clearly shows improvement of soil structure. Biswas et al., (1970) reported that the nature of organic matter played an important role in the development soil structure owing to differential nature of by products produced during the process of decomposition.

\section{Chemical properties of soil}

The effects of various geotextiles which change the chemical properties and nutrient availabilities in soils are presented in (Table
5). The various chemical properties are $\mathrm{pH}$, organic carbon and availabilities of nutrients like nitrogen, phosphorus and potassium contents in soils. Soil $\mathrm{pH}$ and EC values decreases with the application of jute, Dry grasses, coco coir and banana leaf fibre geotextile more than the control plot.

Lowest value of $\mathrm{pH}$ (7.6) and EC $(2.25 \mathrm{mmhos} / \mathrm{cm})$ were found in non-woven jute geotextile and highest value i.e 7.9 and $3.78 \mathrm{mmhos} / \mathrm{cm}$ are found in the control plot. As well as available nitrogen, phosphorus and potassium content are also increase by application of geotextile. The highest value observed by application of jute geotextile is nitrogen $96.75 \mathrm{~kg} / \mathrm{ha}$, phosphorus $33.28 \mathrm{~kg} / \mathrm{ha}$ and potassium $262.94 \mathrm{~kg} /$ ha respectively. The above results collaborate with the observation reported by Rajagopal and Ramakrishna, (1997) for the increasing availabilities of nutrients with the application of various geotextiles.

The value of organic carbon gradually increase by application of treatments following order i.e. jute geotextile 1.37>Dry grasses geotextile 1.27> coco coir geotextile $1.24>$ banana leaves geotextile 1.13> control 1.02. Increases of organic carbon content found highest in the plot under jute geotextile $(34.31 \%)$ over the control.

The above results are in agreement with the observation as reported by Rajagopal and Ramakrishna (1997) who observed improvement of organic carbon content in soil by the application of geotextile. Similar options are also available from the results of Sudhier and Siddaramappa (1995) and Varalashmi et al., (2005) Manna (2005),Dutta and Chakraborty (1995) and Adhikary et al., (2016) also observed increase of organic carbon content in NPK over NP due to significant important of active fraction of soil organic crabon. 
Table.1 Initial soil parameter of the experimental plot

\begin{tabular}{|c|c|c|}
\hline Sl. No. & Particulars & Values \\
\hline A) & Physical properties & \\
\hline 1 & Bulk density $(\mathrm{gm} / \mathrm{cc})$ & 1.28 \\
\hline 2 & Porosity (\%) & 49.9 \\
\hline \multirow[t]{4}{*}{3} & Particle size distribution (\%) & \\
\hline & Sand & 16.1 \\
\hline & Silt & 33.7 \\
\hline & Clay & 49.9 \\
\hline 4. & Water holding capacity (\%) & 51.6 \\
\hline 5 & Soil aggregates & \\
\hline a) & Mean weight diameter (mm) & 0.665 \\
\hline b) & Structural coefficient & 0.601 \\
\hline c) & GMD (mm) & 0.418 \\
\hline d) & WAS $>0.25 \%$ & 58.70 \\
\hline e) & WAS $<0.25 \%$ & 40.26 \\
\hline B) & Chemical Properties & \\
\hline 1. & Soil $\mathrm{pH}(1: 2.5$ soil suspension $)$ & 7.9 \\
\hline 2. & $\mathrm{EC}(\mathrm{mmhos} / \mathrm{cm})$ & 3.8 \\
\hline 3. & Organic carbon (\%) & 0.95 \\
\hline 4. & Available nitrogen (kg/ha) & 22.10 \\
\hline 5. & Available phosphorus (kg/ha) & 20.19 \\
\hline 6. & Available potassium ( $\mathrm{kg} / \mathrm{ha}$ ) & 165.30 \\
\hline
\end{tabular}

Table.2 Experimental Details

\begin{tabular}{|c|c|}
\hline \multirow[t]{5}{*}{ Treatment Details } & $\begin{array}{l}T_{1}: \text { Non woven jute fibre geotextile }(5 \text { ton+ NPK @ } 60: 40: 40 \\
\mathrm{kg} / \mathrm{ha})\end{array}$ \\
\hline & $\begin{array}{l}T_{2}: \text { Non woven dry grasses fibre geotextile.(5 ton+ NPK @ } \\
60: 40: 40 \mathrm{~kg} / \mathrm{ha})\end{array}$ \\
\hline & $\begin{array}{l}\mathrm{T}_{3}: \text { Non woven coco coir geotextile. ( } 5 \text { ton+ NPK @ } 60: 40: 40 \\
\mathrm{~kg} / \mathrm{ha} \text { ) }\end{array}$ \\
\hline & $\begin{array}{l}T_{4}: \text { Non woven banana leaf fibre geotextile. (5 ton+ NPK @ } \\
60: 40: 40 \mathrm{~kg} / \mathrm{ha} \text { ) }\end{array}$ \\
\hline & $\mathrm{T}_{5}:$ Control (farmer practice). (NPK @ $60: 40: 40$ kg/ha) \\
\hline Plot size: & $36 \mathrm{sq} \mathrm{m.}$ \\
\hline Design: & RBD \\
\hline Replication: & 3 \\
\hline Date of planting & January $2^{\text {nd }} 2015$ \\
\hline
\end{tabular}


Table.3 Physical Properties of Soil

\begin{tabular}{|l|c|c|c|}
\hline \multicolumn{1}{|c|}{ Treatment } & Bulk density(g/cc) & Porosity (\%) & $\begin{array}{c}\text { Water holding } \\
\text { capacity (\%) }\end{array}$ \\
\hline Jute & 1.20 & 56.47 & 60.97 \\
\hline Dry grasses & 1.23 & 55.57 & 59.00 \\
\hline Coco coir & 1.25 & 51.77 & 55.47 \\
\hline Banana leaf fibre & 1.27 & 51.17 & 53.43 \\
\hline Control & 1.28 & 49.90 & 51.50 \\
\hline SEm( $\mathbf{( )}$ & 0.01 & 0.24 & 0.31 \\
\hline CD at 5\% & 0.02 & 0.78 & 1.02 \\
\hline
\end{tabular}

Table.4 Soil Structure

\begin{tabular}{|l|c|c|c|c|c|}
\hline \multicolumn{1}{|c|}{ Treatment } & $\begin{array}{c}\text { MWD } \\
(\mathbf{m m})\end{array}$ & $\begin{array}{c}\text { Structural } \\
\text { coefficient }\end{array}$ & GMD (mm) & $\begin{array}{c}\text { WAS }>\mathbf{0 . 2 5} \\
\mathbf{\%}\end{array}$ & WAS<0.25\% \\
\hline & 1.960 & 0.976 & 0.813 & 85.757 & 16.453 \\
\hline Jute & 1.741 & 0.971 & 0.764 & 80.690 & 17.780 \\
\hline Dry grasses & 1.351 & 0.893 & 0.678 & 74.743 & 25.807 \\
\hline Coco coir & 1.140 & 0.883 & 0.667 & 69.653 & 31.070 \\
\hline $\begin{array}{l}\text { Banana leaf } \\
\text { fibre }\end{array}$ & 0.752 & 0.646 & 0.474 & 62.200 & 39.820 \\
\hline Control & 0.010 & 0.000 & 0.010 & 0.240 & 0.240 \\
\hline SEm( $(\mathbf{)}$ & 0.050 & 0.000 & 0.020 & 0.770 & 0.770 \\
\hline CD at 5\% & & & & & \\
\hline
\end{tabular}

Table.5 Chemical Properties of Soil

\begin{tabular}{|c|c|c|c|c|c|c|}
\hline Treatment & pH & $\begin{array}{c}\text { EC } \\
(\text { mmhos/cm) }\end{array}$ & $\begin{array}{c}\text { Organic } \\
\text { carbon } \\
(\%)\end{array}$ & $\begin{array}{c}\text { Available } \\
\text { Nitrogen } \\
\text { (Kg/ha) }\end{array}$ & $\begin{array}{c}\text { Available } \\
\text { phosphorus } \\
\text { (Kg/ha) }\end{array}$ & $\begin{array}{c}\text { Available } \\
\text { Potassium } \\
\text { (Kg/ha) }\end{array}$ \\
\hline Jute & 7.67 & 2.25 & 1.37 & 96.75 & 33.28 & 262.94 \\
\hline Dry grasses & 7.63 & 2.91 & 1.27 & 85.19 & 31.05 & 247.38 \\
\hline Coco coir & 7.57 & 3.15 & 1.24 & 80.52 & 34.25 & 218.04 \\
\hline $\begin{array}{c}\text { Banana leaf } \\
\text { fibre }\end{array}$ & 7.47 & 3.49 & 1.13 & 75.45 & 29.97 & 212.29 \\
\hline Control & 7.90 & 3.78 & 1.02 & 26.99 & 24.80 & 159.44 \\
\hline $\operatorname{SEm}( \pm)$ & 0.06 & 0.04 & 0.02 & 1.01 & 0.30 & 1.96 \\
\hline CD at $5 \%$ & 0.20 & 0.13 & 0.08 & 3.28 & 0.98 & 6.38 \\
\hline
\end{tabular}


The results of present study thus lead to suggest that application of each of geotextiles increased growth and yield of vegetables. It also helps to improve physical and chemical properties in soil particularly the structural status in soil and also enhanced the water use efficiency and crop growth rate by the crops.

Besides, each at the applied geotextile facilitates to increase soil organic carbon and build up soil fertility. Among the various geotextiles used for the study jute geotextile found to be more effective for improving soil properties and building up soil fertility.

\section{References}

Adhikary, N.,Disha, A., Mahata, A.P., Pal, A., Adhikary, R., Sardar, M., Saha, A., Bauri, S.K., Tarafdar, P.K., and De, S.K. 2016.Journal of Soil and Water Conservation 15(3): 242-245, JulySeptember 2016

Adhikary, R and Pal, Arunabha 2019 Geotextile and its Importance in Agriculture: A Review Study. International Journal of Bioresource Science. 6(2): 61-63 December 2019.

Bhattacharyya, R., Davies, K., Fullen, M. A. and Booth,C. A. 2010. Soil conservation using palmmatgeotextiles on loamy sand soils in the UnitedKingdom.

Biswas, T.D., Roy, M.R. and Sahu, B.N. 1970. Effect of different sources of organic manure on the physical properties of the soil growing rice, Journal of Indian society of soil science, 18: 223-242.

Booth, C.A., Davies, K. and Fullen, M.A. 2005. Environmental and socioeconomic contribution of palm- leaf geotextile to sustainable development and conservation, pp. 649-658.

Dutta, T. and Chakraborty, T. (1995). Effect of organic manures and subabul
(Laucaena leucocephala) leaf mulching under varying levels of fertility on growth and yield of potato ((Solanumtuberosum) and weed biomass. Indian Journal of Agronomy. 40(1): 140-142.

Manna, M.S., Swarup, A., Wangar, R.H., Ravankar, H.N., Mishra, B., saha, M.N., Singh, Y.V., Sahi, D.K. and Sarap, P.A. (2005). Long term effect of fertilizer and manure application on soil organic carbon, soil quality and yield sustainability under sub - humid ad semi-arid tropical India. Field crop Research. 93(2-3): 264-280.

Nag, D., Choudhury, T. K., Debnath, S., Ganguli, P. K.and Ghosh, S. K. 2008. Efficient management of soilmoisture with jute non-woven as mulch forcultivation of sweet lime and turmeric in red lateriticzone. Journal of Agri. Engg.45(3): 59-62.

Pain, Debabrata, De, Susanta Kumar, Tarafdar, P. K.,Pal, Arunabha, Mahata, Angira Prasad, Adhikari,R. and Bauri, S.K. 2013. Efficient use of geotextiles as soil conditioner to increase potato productivity on inceptisols of West Bengal. Journal of Soil andConservation 12(2):103-107.

Rajagopal, K. and Ramakrishna, S. 1997. Degradation behavior of coco geotextiles with in clay soils. Proc. Of Asian Regional Conf. on Geosynthesis, pp. 25-29.

Sudhir, K. and Siddaramappa, R. (1995). Role of organic manure in the maintenance of soil helth and productivity - An experience from long term fertilizer experiment at Bangalore centre. In: Alternative of Fertilizer in sustainable Agriculture. K. Shivashankar (ed.), University of Agricultural Sciences, Bangalore.

Varalakshmi, L.R., Srinivasamurthy and Bhaskar, S. (2005). Effect of 
integrated use of organic manure and inorganic fertilizers on organic carbon, available $\mathrm{N}, \mathrm{P}$ and $\mathrm{K}$ in sustaining productivity of Groundnut - Finger Millet cropping system. Journal of the Indian Society of soil Science.53(3):
315-318

Yong, L. H., ZaiQin, W., DingXing, P. and GuoSheng, L. 2000. Study on the effect of jute geotextile on rime growth. Journal of Scientia Agricultura Sinica33(3):103-105.

\section{How to cite this article:}

Arunabha Pal, Rahul Adhikary, Monisankar Bera, Susnata Kumar De and Milan Sardar. 2020. Application of Different Geotextile in Soil to Improve the Soil Health in Humid and Hot Sub Humid Region of West Bengal. Int.J.Curr.Microbiol.App.Sci. 9(06): 2812-2818. doi: https://doi.org/10.20546/ijcmas.2020.906.340 